\title{
A botanical and pharmacological description of petasites species
}

\author{
Jerzy Tys ${ }^{1}$, Aleksandra Szopa ${ }^{2}$, Justyna Lalak ${ }^{1}$, Mariola Chmielewska ${ }^{1}$, \\ Anna Serefko ${ }^{2}$, Ewa Poleszak ${ }^{2 *}$
}

${ }^{1}$ The Bohdan Dobrzanski Institute of Agrophysics of the Polish Academy of Sciences, Doswiadczalna 4, 20-290 Lublin, Poland ${ }^{2}$ Chair and Department of Applied Pharmacy, Medical University of Lublin, Chodzki 1, 20-093 Lublin, Poland

\begin{tabular}{|c|c|}
\hline ARTICLE INFO & ABSTRACT \\
\hline $\begin{array}{l}\text { Received } 03 \text { June } 2015 \\
\text { Accepted } 21 \text { July } 2015\end{array}$ & \multirow{2}{*}{$\begin{array}{l}\text { The objective of this review was to evaluate the botanical and pharmacological } \\
\text { description of Petasites species. Petasides (butterbur) as a perennial shrub which was } \\
\text { found in Europe and also in a parts of Asia and North America, has been widely used } \\
\text { medicinally for centuries. At present, the main phytopharmacology uses for Petasides } \\
\text { extracts are for prophylactic treatment of migraines, as well as an antispasmodic agent for } \\
\text { bronchial asthma and pertussis. Furthermore, it has been used effectively in preventing } \\
\text { gastric ulcers, and in urinary tract spasms and treating patients with irritable bladder. But } \\
\text { still, there is a need for more studies on the potential applications of butterbur extract in } \\
\text { medicine. }\end{array}$} \\
\hline $\begin{array}{l}\text { Keywords: } \\
\text { butterbur, } \\
\text { pharmacological studies, } \\
\text { clinical trials, } \\
\text { migraine, } \\
\text { asthma, gastroenteritis. }\end{array}$ & \\
\hline
\end{tabular}

\section{HISTORY}

The genus name Petasites comes from the Latin petasus - a hat worn by travelers - butterbur (Petasites) leaves being used for this purpose by country folk. The plant, however, had medicinal purposes, Nicholas Culpeper wrote in his English Physician (1652) that butterbur root was "very available against the plague, and pestilential fevers, by provoking sweat". This effect gave it the other common name, 'Plagueflower'. Of note: the name 'Butterbur' is supposed to have been given because, these large leaves used to be wrapped around butter during hot weather. 'Lagwort' is another common name of this plant, and came about in reference to the leaves delaying their appearance till after the flowers have faded. In Germany, another old name for the plant was Pestilenzenwurt. This name was given it as an indication of its value as a remedy in times of pestilential calamity [18].

\section{TAXONOMY}

Petasites Mill. (Asteraceae) (common butterbur or Sweet Coltsfoot.) has a long history of use in alternative medicine in the treatment of certain illnesses (usually for spasmolytic and anti-inflammatory purposes) [25], and a taxonomic survey of butterbur reveals the existence of 18 species of

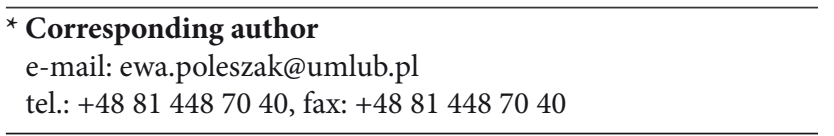

this genus [36]. Butterbur taxa have a broad distribution in the Northern hemisphere, from North Africa to Eastern Asia, and from North America to throughout Europe. In the European continent, eight native species can be naturally found, and another two: $P$. japonicus and P. fragrans have been introduced [25]. In Poland, four Petasites taxa are frequently encountered; they occupy wetland habitats: the banks of rivers, streams, spring-fens, as well as moist forests $[25,27,32]$. The most common species in Poland is P. hybridus (L.) P. Gaertn., B. Mey. \& Scherb. (= P. officinalis Moench), which is widespread from Pomerania, to the upper subalpine zone of the Sudetes and Carpathians. Another species in term of incidence is P. albus (L.) Gaertn., which has been found in numerous mountain localities and less commonly in Silesia, Lesser Poland and the Lublin Uplands, as well as in Pomerania [25]. In Poland, an additional species, $P$. spurius (Retz.) Rchb. grows mainly on the sandy banks of large rivers (the Vistula, the Bug River, the Oder and the Warta) and on the shoreline of the Baltic Sea. The last native taxon of butterbur, which occurs frequently in the Carpathians and probably in only one stand in the Polish side of the Giant Mts, is P. kablikianus Tausch ex Bercht. $[5,25,27,32,37,38,46]$. Petasites is a taxonomically hard group of plants to describe due to the conservative floral structure and the high variability of the leaves. In addition, these species form hybrids. Therefore, there are different classifications of Petasites genus, and, for instance, in North 
America, one to ten species are distinguished [11,12]. Petasites are also occasionally confused with coltsfoot. As well, for pharmaceutical purposes, contamination with Tussilago farfara raw material can come about. On the other hand, both taxa are easy to differentiate, and they differ in flowers and also in the size and shape of their leaves [13,20,25].

\section{HABITATS}

The species which belong to the Petasites genus occupy a very diverse environment. However, the plant grows preferably in partial shade, but if there is appropriate amount of water, it can grow in full sun. Butterbur grows most luxuriantly and plentifully in humid thickets, along the banks of streams, ditches, ravines and rivers, and in some places, it generates large, single-species clusters. It prefer humus soil, as well as periodically waterlogged soil. Petasites spp are plants well adapted to surviving the winter condition (being a hemicryptophyte, it forms a rosette, the growth bud being protected in winter by way of a layer of litter composed of dead and living leaves). Moreover, it is an indicator of welloxygenated soils $[25,36]$.

\section{CHARACTERISTICS}

Butterbur species are perennial herbs with thick rhizomes and usually enormous leaves [26]. Yet, species belonging to the Petasites genus differ in flower color, size, shape and hairiness of leaves, ribbing of petioles, as well as size and shape of the scale leaves on the flowering stems, etc. [27, 33]. The leaves are normally kidney- or heart-shaped, irregularly serrated, their tops being green and smooth, while their bottoms being light gray and fuzzy. The petioles of common butterbur are hollow. The first leaves appear after the flowering of the plant, while the late-blooming leaves are bare and green on both sides. The flowers are reddish, and sometimes even white. It is a dioecious plant which contains numerous male flowers, peripheral tubular female flowers and a large amount of fruitless hermaphrodite flowers. Common butterbur blooms in the months of April- May. The primary florescence is collected in a head, and the plant forms paniclelike or racemose secondary inflorescences. The leaves and flowers also secrete a characteristic odor. Common butterbur develops flower-carrying stems that reach heights of up to $80 \mathrm{~cm}$ [13]. The fruit of butterbur is wind-dispersed.

\section{CULTIVATION AND PROPAGATION DETAILS}

Butterbur have very specific soil requirements. These plants grow best in moist and heavy soils, but also in well-drained soils rich in oxygen. Although it tolerates an ordinary garden soil, it grows best in fertile humus soils which are constantly moist, and have a $\mathrm{pH}$ between 4.5 and 5.5. When the conditions of cultivation are good, the plants could be highly aggressive and invasive, because the smallest piece of rhizome left in the ground will quickly form a sturdy new plant $[11,12]$.

Butterbur is generally propagated by its seeds, but this species may also be propagated by division. Propagation by softwood cuttings is also very popular. The cut plants are placed in a humid medium that is relatively shallow, and it is important to maintain a high substrate temperature (typically $20-25^{\circ} \mathrm{C}$, these values are, however, dependent on the species), as well as high humidity. The substrate for rooting such cuttings should be sterile in the top layer and partly coarse (thus ensuring adequate aeration). The bottom layer should contain nutrients in a starting dose. The substrate for planting should also be kept moist. Cuttings for butterbur propagation should be sought from strong, well developed, leafy young shoots, because that which are weak, often rot and do not take root. For such cuttings, separate the tip of the shoot, so as to prevent flowering, or cut it into segments (containing at least one leaf whorl) if it is too long. Depending on the species of plants, cuttings should be $6-10 \mathrm{~cm}$ long and have 3-5 healthy leaves. The use of a razor to make such cuttings is recommended, so as to ensure that the cut is smooth, perpendicular to the stem and not less than $2 \mathrm{~mm}$ below the node from where the leaf grows. Such cuttings rapidly root $[18,45]$.

\section{ACTIVE SUBSTANCES FROM PETASITES AND THEIR MECHANISM OF ACTION}

The main active substances isolated from the butterbur rhizomes, roots, and leaves are petasin and isopetasin. These substances belong to the sesquiterpenes. In addition to sesquiterpenes, pyrrolizidine alkaloids, flavonoids, essential oils, and tannins are also found in butterbur extracts [3, 24]. The pharmacological action of petasin and isopetasin was already seen in the 1950s [8]. Since then, most of the studies have focused on the mechanism of action, efficacy, and safety of Petasites hybridus extracts. In this regard, the antispasmodic activity of the methanolic extract of the fresh roots has been demonstrated [8]. In turn, lipophilic extracts of butterbur roots have been found to preferentially inhibit the activity of cyclooxygenase 2 (COX-2) [15]. Moreover, the results of in vitro studies have demonstrated that ethanol extracts of butterbur root and leaves inhibit the lipoxygenase pathway [35].

Petasin and its isomers (i.e., isopetasin and neopetasin) are known to be anti-inflammatory substances. They both inhibit the synthesis of peptide-leukotriene, whilst petasin also blocks the release of the eosinophil cationic protein [35]. Additionally, petasin inhibits contractions induced by histamine, carbachol, and the accumulation of calcium ions $[19,41,44]$. It follows that non-specific antispasmodic and antimuscarinic effects are responsible for the myorelaxant activity of petasin [2]. Of note: the pyrrolizidine alkaloids found in Petasites exhibit hepatotoxic and carcinogenic activity. Therefore, it is necessary to remove these from the extract prior to its use $[3,9,10]$.

\section{CLINICAL APPLICATION OF PETASITES EXTRACTS}

Researchers coming from various medical disciplines have shown interest in the therapeutic use of butterbur extracts $[39,40,43]$. Since butterbur extract relaxes smooth muscles and possesses anti-inflammatory properties, it could be helpful in urinary tract problems, menstrual pain and cramps, migraine headaches, as well as in easing the 
symptoms associated with nephrolithiasis or gastrointestinal colics and dysmenorrhoea $[1,2,14]$. Moreover, it could see use in the treatment of bronchial asthma and pertussis [23].

\section{Migraine headaches}

Several studies have shown that standardized extracts from the rhizome of Petasites are effective in the prophylaxis of migraine [2,16,22]. Twice daily application of this extract at a dose of $50 \mathrm{mg}$ for three months has been shown to result in a decrease in the frequency of attacks and the number of migraine days per month [16,17,23,24]. What is more, both reduction of symptoms associated with migraine and decreased duration and intensity of pain were noted [22-24]. In addition, the efficacy of the standardized extracts from the rhizome of Petasites was comparable to that achieved with drugs considered to be effective in preventing migraine, such as the calcium antagonists [30,31], the $\beta$-blockers $[34,42]$, as well as the serotonin antagonists [28]. Approximately $60 \%$ of all patients treated with butterbur extract experienced a decrease in headache frequency $[16,17]$. Furthermore, therapy with butterbur extract has been generally well-tolerated by all patients, and no side effects have been observed [23,24].

\section{Bronchitis and asthma}

For centuries, Petasites leaves, roots and rhizomes have been used in traditional medicine as a remedy for asthma, whooping cough, and mucus cough $[23,24]$. The high efficiency of butterbur in treating bronchitis, asthma and other inflammatory conditions of the upper respiratory tract is attributed to the presence of petasin. This acts as a spasmolytic on smooth muscle and has anti-inflammatory properties $[6,21,39,40]$. It was demonstrated in medical research that in patients receiving $1800 \mathrm{mg}$ of butterbur extract per day (in divided doses), a considerable improvement in forced expiratory volume (FEV1) has come about [47]. Moreover, this improvement was larger than that observed in patients treated with corticosteroids [47]. Petasin is known to suppress lymphocytes, neutrophils, as well as eosinophils, and to decrease levels of cytokines such as interleukin, tumor necrosis factor (TNF- $\alpha$ ) and interferon (IFN- $\gamma$ ) in bronchoalveolar fluid. This could at least partially explain the mechanism of action of this sesqiterpene in bronchial diseases [25,29]. Accordingly, Petasites extract has a potential to be an efficient agent in the therapy of asthma and bronchitis, in addition to other inflammations of the upper respiratory tract.

\section{Gastroenteritis}

Butterbur leaves and rhizomes have been employed as an antispasmodic in gastrointestinal disorders since the Middle Ages. Primarily, the extract from these parts of the Petasites species was used for alleviating colic, cramps, and the hindered outflow of bile [4]. However, studies performed by Brune et al. [7] also suggest that an ethanolic extract of butterbur prevents the intestinal mucosal damage brought about by abuse of alcohol, and reduces the small intestinal ulceration induced by administration of anti-inflammatory drugs, e.g. indomethacin $[4,25]$. The effect on gastroenteritis is most probably attributed to the suppression of leukotriene synthesis and the inhibition of lipoxygenase activity $[4,25,35]$.

What is important to remember is that butterbur extracts deprived of all toxic alkaloids alone be used for therapeutic purposes. Because of the fact that the currently employed methods of removing undesirable alkaloids are very expensive and time-consuming, it is necessary to research and implement new procedures. However, not all of the mechanisms of action of the active ingredients of Petasites are well documented and understood. Consequently, there is a need for further studies on the potential applications of butterbur extract in medicine.

\section{REFERENCES}

1. Agostia R. et al.: Effectiveness of Petasites hybridus preparations in the prophylaxis of migraine: A systematic review. Phytomed., 13, 743, 2006.

2. Aydin A.A. et al.: The medical plant butterbur (Petasites): analytical and physiological (re)view. J. Pharm. Biomed. Anal., 75, 220, 2013.

3. Aydin A.A., Letzel T.: Simultaneous investigation of sesquiterpenes, pyrrolizidine alkaloids and $\mathrm{N}$-oxides in Butterbur (Petasites hybridus) with an offline 2D-combination of HPLC-UVandLCMMI-ToF-MS. J. Pharm. Biomed. Anal., 85, 74, 2013.

4. Blumenthal M., editor (1998). The Complete German Commission E Monographs. Austin, TX: American Botanical Council.

5. Broda B., Mowszowicz J., editors (2000). Przewodnik do oznaczania roślin leczniczych, trujących i użytkowych. Warszawa: Polskie Wydawnictwo Lekarskie PZWL.

6. Brune K. et al.: Europaeische Patentanmeldung 0-281-656 vom. 19.09.88. Europaeisches Patentamt: Patentblatt 88/37 (1988).

7. Brune K., Bickel D., Peskar B.A.: Gastro-protective effects by extracts of Petasites hybridus: the role of inhibition of peptido-leukotriene synthesis. Planta. Med., 59, 494, 1993.

8. Bucher, K.: Uber ein antispastisches Prinzip in Petasites officinalis Moench. Arch. Exp. Path. Pharmacol., 213, 69, 1950.

9. Bull L.B., Dick A.T., McKenzie J.S.: The acute toxic effects of heliotrine and lasio- carpine and their n-oxides, on the rat. J. Path. Bact., 75, 17, 1958.

10. Bull L.B., Dick A.T.: The chronic pathological effects on the liver of the rat of the pyrrolizidine alkaloids heliotrine, lasiocarpine and their n-oxides. J. Path. Bact., 78, 483, 1959.

11. Cherniawsky D.M., Bayer R.J.: Systematics of North American Petasites (Asteraceae: Senecioneae). I. Morphometric analyses. Can. J. Bot., 76, 23, 1998.

12. Cherniawsky D.M., Bayer R.J.: Systematics of North American Petasites (Asteraceae: Senecioneae). III. A taxonomic revision. Can. J. Bot., 76, 2061, 1998.

13. Debrunner B., Meier B.: Petasites hybridus: a tool for interdisciplinary research in phytotherapy. Pharm. Acta. Helv., 72(6), 359, 1998.

14. Eaton J.: Butterbur, herbal help for migraine. Nat. Pharm., 2(1), 23, 1998.

15. Fiebich B.L. et al.: Petasites hybridus extracts in vitro inhibit COX-2 and PGE2 release by direct interaction with the enzyme and by preventing $\mathrm{p} 42 / 44 \mathrm{MAP}$ kinase activation in rat primary microglial cells. Planta. Med., 71, 12, 2005.

16. Grossman W., Schmidramsl H.: An extract of Petasites hybridus is effective in the prophylaxis of migraine. Altern. Med. Rev., 6, 303, 2001.

17. Grossmann W.M., Schmidramsl H.: An extract of Petasites hybridus is effective in the prophylaxis of migraine. Int. J. Clin. Pharmacol. Ther., 38, 430, 2000.

18. Jennings N.L., editor (2008). Coastal Beauty: Wildflowers and Flowering Shrubs of Coastal British Columbia and Vancouver Island. Calgary: Rocky Mountain Books.

19. Ko W.C. et al.: Mechanisms of relaxant-action of S-petasin and S-isopetasin, sesquiterpenes of Petasites formosanus in isolated guinea pig trachea. Planta. Med., 67, 224, 2001. 
20. Kwaśniewska J.: Podbiał (Tussilago L.) a lepiężnik (Petasites Mill.) Ziel. Biul. Inf., 10(1), 11, 1958.

21. Lee K.P. et al.: Therapeutic Effects of S-Petasin on Disease Models of Asthma and Peritonitis. Biomol. Ther., 23(1), 45, 2015.

22. Lipton R.B. et al.: Petasites hybridus root (butterbur) is an effective preventive treatment for migraine. Neurol., 63, 2240, 2004.

23. Mauskop A., Grossmann W.M., Schmidramsl H.: Petasites hybridus (butterbur root) extract is effective in the prophylaxis of migraines. Results of a randomized, double-blind trial. J. Head. Face. Pain., 40, 4, 2000.

24. Mauskop A.: Petasites hybridus: an ancient medicinal plant is an effective prophylactic treatment for migraine. Townsend. Lett., 202, $104,2000$.

25. Ożarowski M., Przystanowicz J., Adamczak A.: Phytochemical, pharmacological and clinical studies of Petasites hybridus (L.) P. Gaertn., B. Mey. \& Scherb. A review. Herb. Pol., 59(4), 108, 2013.

26. Preston C.D., Pearman D.A., Dines T.D., editors (2002). New Atlas of the British and Irish Flora. Oxford: Oxford University Press.

27. Rutkowski L., editor (1998). Klucz do oznaczania roślin naczyniowych Polski niżowej. Warszawa: Wydawnictwo Naukowe PWN.

28. Ryan R.E.: A new preparation for the interval treatment of migraine. Headache, 11, 6, 1971.

29. Shih C.H. et al.: S-petasin, the main sesquiterpene of Petasites formosanus, inhibits phosphodiesterase activity and suppresses ovalbumin-induced airway hyperresponsiveness. Evid. Bas. Complem. Alternat. Med., 4, 132, 2011.

30. Siniatchkin M., Gerber W.D., Vein A.: Clinical efficacy and central mechanisms of cyclandelate in migraine: a double-blind placebo controlled study. Funct. Neurol., 13, 47, 1998.

31. Soyka D., Östreich W.: Flunarizine vs. propanolol in the interval treatment of migraine: A multi-center, double-blind study from practicing general medical doctors and internists. Nervenheilkunde, $19,45,1990$.

32. Szafer W., Kulczyński S., Pawłowski B., editors (1986). Rośliny Polskie vol. II. Warszawa: Wydawnictwo Naukowe PWN.

33. Tan K. et al.: On a new Petasites species from the southern Pindos (Greece). Phytol. Balcan., 16(2), 243, 2010.

34. Tfelt P. et al.: Timonol vs propanolol in common migraine prophylaxis. A double-blind multi-center trial. Acta. Neuol. Scand., 69, 1, 1984.
35. Thomet O.A.R. et al.: Differential inhibition of inflammatory effector functions by petasin, isopetasin and neopetasin in human eosinophils. Clin. Exp. Allergy., 31, 1310, 2001.

36. Toman J.: A taxonomic survey of the genera Petasites and Endocellion. Folia. Geobot. Phytotax., 7, 381, 1972.

37. Uziębło A.K. (2004). Subalpine populations of Petasites kablikianus Tausch ex. Bercht. in the Babia Góra and in the Karkonosze National Parks. In: Geoekologické problémy Krkonoš. Štursa J., Mazurski K.R., Palucki A., Potocka J. (editors). Opera Corcontica; p. 135.

38. Uziębło A.K.: Petasites kablikianus Tausch ex Berchtold as a pioneer species and its abilities to colonise initial habitats. Pr. N. U. Ś., 2886, $1,2011$.

39. Wang Y.L. et al.: Bakkenolides from Petasites tricholobs and their neuroprotective effects related to antioxidant activities. Planta. Med.,75, 230, 2009.

40. Wang Y.L., Guo M., Wang Y.: Quality evaluation of Petasites tricholobus through simultaneous determination of four bioactive bakkenolides by LC. Chromatograph., 70, 1367, 2009.

41. Wang, G.J. et al.: Ca2+ channel blocking effect of iso-S-petasin in rat aortic smooth muscle cells. Eur. J. Pharmacol., 445, 239, 2002.

42. Weerasuriya K., Patel L., Turner P.: Beta-adreno-receptor blockade and migraine. Cephalalg., 2, 33, 1982.

43. Wildi E. et al.: Quantitative analysis of petasin and pyrrolizidine alkaloids in leaves and rhizomes of in situ grown Petasites hybridus plants. Plant. Med. 64, 264, 1998.

44. Wu S.N., Chen H., Lin Y.L.: The mechanism of inhibitory actions of S-petasin, a sesquiterpene of Petasites formosanus, on L-type calcium current in NG108-15 neuronal cells. Planta. Med., 69, 118, 2002.

45. Yuzuri I., Wataru N.: New Japanese Butterbur Variety with High Yield and High Quality. Breed. Sci., 57(3), 249, 2007.

46. Zając A., Zając M., editors (2001). Atlas rozmieszczenia roślin naczyniowych w Polsce. Kraków: Pracownia Chorologii Komputerowej Instytutu Botaniki Uniwersytetu Jagiellońskiego.

47. Zioło G, Samochowiec L.: Study on clinical properties and mechanism of action of Petasites in bronchial asthma and chronic obstructive bronchitis. Pharmaceut. Act. Helv., 72, 359, 1998. 